\title{
Marcin Urynowicz, Adam Czerniaków 1880-1942. Prezes getta warszawskiego, Instytut Pamięci Narodowej, Warszawa 2009
}

Autor, pracownik naukowy Biura Edukacji Publicznej Instytutu Pamięci Narodowej, od wielu lat zajmuje się tematyką getta warszawskiego, stosunkami polsko-żydowskimi w okupowanej Warszawie i generalnie badaniami nad najnowszymi dziejami polskich Żydów. Jak na stosunkowo młody wiek sporo publikował, i to zarówno w wydawnictwie IPN, jak i Żydowskiego Instytutu Historycznego. Dał się poznać jako dobry znawca języka jidysz, co nie jest częste wśród badaczy żydowskiej Warszawy, a także jako zwolennik poglądu o dużym zakresie polskiej pomocy dla prześladowanej w latach niemieckiej okupacji ludności żydowskiej. Przygotowywanej od kilku lat rozprawy doktorskiej poświęconej Adamowi Czerniakowowi koleżanki i koledzy po fachu oczekiwali z dużym zainteresowaniem. Czy wynik jego pracy wszystkich usatysfakcjonował, szczerzę wątpię, choć nie winiłbym za to przede wszystkim autora. Biografia naukowa każdej znanej, ważnej i wręcz symbolicznej osoby, a z taką mamy do czynienia w przypadku Czerniakowa, zazwyczaj jest głównie opowieścią historyczną o jego czasach, dalej prezentacją dokonań bohatera, a dopiero na końcu biografią intymną i osobistą, na którą liczą czytelnicy masowi. Autor $\mathrm{z}$ reguły swojego bohatera lubi i szanuje, pisze więc o nim z szacunkiem, słowami i zdaniami wyważonymi, nie dając wiary jego przeciwnikom i wrogom. Dla porażek i słabości swojego bohatera zawsze znajdzie jakieś wytłumaczenie, w ostateczności je zbagatelizuje. Na dodatek bohater recenzowanej biografii żył dosyć długo, i to w czasach przypadających na dwie niedające się ze sobą porównać epoki. Niemniej jednak o sukcesie i wadze książki decyduje zawsze zarówno kompletność kwerendy źródłowej, jak warsztat naukowy autora i jego talent pisarski.

Jeśli chodzi o bazę źródłową recenzowanej książki, to w prawie trzynastostronicowej bibliografii w zasadzie niczego nie brakuje. Autor pracował aż w dziewięciu archiwach, przeprowadził wywiady z żyjącą dziś rodziną bohatera, przeczytał wszystkie napisane przez niego przed wojną artykuły fachowe oraz całe mnóstwo książek i artykułów dotyczących czasów, w których żył Czerniaków. Przeważają jednak materiały dotyczące przełomu XIX i XX w. oraz dwudziestolecia międzywojennego, spośród specjalistów czasów Zagłady brakuje kilku nazwisk badaczy, którzy w ostatnich latach wnieśli spory wkład w lepsze ich poznanie, np. Ch. Browninga, S. Kassowa, P. Longericha, kilku autorów biografii Marka Edelmana. Wspomniana dysproporcja nieco zaskakuje, zważywszy, że w biografii prawie tyle samo stron poświęcono okresowi do 1 września 1939 r., co niecałym trzem latom okupacji.

Motywy, które kierowały Urynowiczem w momencie podejmowania decyzji o podjęciu pracy nad biografią, przekonują, gdyż dla uratowanych z Zagłady Żydów Czerniaków był rzeczywiście dosyć długo postacią ambiwalentną; wiele osób 
zarzucało mu, że nie wezwał warszawskich Żydów do powstania, że stchórzył, wybierając samobójstwo. By wyrobić sobie własne zdanie o jego faktycznej roli w ostatnim rozdziale dziejów warszawskiego żydostwa, autor postanowił postawić „pytania dotyczące pochodzenia, rodziny, wykształcenia, kariery zawodowej, społecznej i politycznej”. Pisząc o pracy Czerniakowa w getcie, nie stawiał sobie jednak celów zbyt dalekich, nie pisał historii getta, lecz jedynie biografię przewodniczącego zarządzającego nim Judenratu. Ograniczenie ze wszech miar słuszne. Na marginesie tych uwag dodam, że wolę określenie „przewodniczący Judenratu” bądź Rady Żydowskiej niż stosowany przez Urynowicza termin „prezes getta”. Getto wszak nie było klubem sportowym ani jakimś dobrowolnym stowarzyszeniem czy spółką, a uzus językowy takie skojarzenia automatycznie podpowiada.

Poważniejsze zastrzeżenia budzi inny zabieg metodologiczny autora. Pisze on, że „najlepszym, bo najbardziej szczegółowym, a przy tym i obiektywnym źródłem do badania jego losów w okresie okupacji są czynione przez niego na bieżąco zapiski. Dzięki temu jesteśmy też w stanie lepiej dostrzec główne problemy, przed którymi stawał i które go nękały. Nawet jeśli nie pisał o nich wprost albo poświęcał im bardzo mało miejsca”. To bardzo ograniczona perspektywa, tym bardziej że jeden z zeszytów się nie zachował i nie wiemy, co zapisano w nim jako ważne uwagi między 14 XII 1940 a 22 IV 1941 r. Nasza wiedza o warszawskim getcie jest już wystarczająca, by wychodzić raczej od katalogu problemów, z którymi borykali się zamknięci w nim ludzie, i na ich kanwie analizować działalność przewodniczącego Judenratu, niż bezkrytycznie ufać, że wszystkie problemy nie dość, że dostrzegł, to także uczciwie zapisał w dzienniku. Historyk nie może ograniczyć się do roli adwokata bohatera swojej narracji, choćby w jego niewinność święcie wierzył.

Z czternastu rozdziałów plan pierwszych ośmiu nie budzi żadnych uwag, dotyczą one bowiem dzieciństwa, edukacji, studiów i pracy zawodowej i społecznej. Od rozdziału ósmego zaczyna się wojenna epopeja warszawskich Żydów i samego Czerniakowa, ujęta w ramy katalogu problemowego, a nie narracji chronologicznej. Wyróżnia się w tym planie rozdział 11, w którym - jak pisze Urynowicz - „został zaprezentowany stosunek Czerniakowa do spraw polskich”. Dla autora jest to najwidoczniej bardzo ważna kwestia, gdyż jak konkluduje we wstępie, „Niniejsza publikacja, jakkolwiek dotyczy życia i śmierci jednego tylko człowieka, odzwierciedla w jakimś stopniu tak dzieje społeczności żydowskiej w Polsce, jak i losy ludności polskiej oraz ich wzajemne, lepsze lub gorsze relacje”. Rzecz jednak w tym, w jakim stopniu?

Studia politechniczne w Warszawie Adam Czerniaków ostatecznie ukończył w 1912 r., był wówczas człowiekiem znającym nieco Europę - studiował także w Dreźnie, był też raczej niezależny materialnie i niezbyt silnie związany ze środowiskiem tradycyjnych religijnie Żydów warszawskich. W okresie studiów nawiązał szereg ważnych na całe swoje życie przyjaźni, głównie w kręgach zasymilowanej młodzieży żydowskiej z warstwy drobnomieszczańskiej, choć miał też znajomych w kręgach socjalistycznych. Pierwsze doświadczenia zawodowe w dziedzinie oświaty zdobył, pracując na Uniwersytecie dla Wszystkich, w szkole rzemieślniczej 
przy gminie żydowskiej i w Towarzystwie Kultury Polskiej. Po odzyskaniu przez Polskę niepodległości pracował w Ministerstwie Robót Publicznych, warszawskim oddziale Jointu, bankowości spółdzielczej i ruchu rzemieślniczym. Od końca lat dwudziestych udzielał się w Radzie Miejskiej Warszawy, a w latach trzydziestych także we władzach gminy żydowskiej. Od 1937 r. zasiadał w komisarycznym zarządzie gminy, którym kierował Maurycy Mayzel.

Sytuacja osobista Czerniakowa zmieniła się radykalnie 6 września, gdy przewodniczący Mayzel nagle zniknął z Warszawy. Ktoś musiał się sprawami gminnymi zajmować i po kilku dniach wziął się do nich on sam. Przypadek czy poświęcenie i oddanie służbie publicznej, a może osobista ambicja? Urynowicz tego problemu nie rozwiązuje, dopuszczając chyba po trosze wszystkie możliwości. Jak wiemy ze wspomnień Apolinarego Hatglasa, z nominacji na przewodniczącego gminy Czerniaków był bardzo dumny. W czasie kampanii wrześniowej ze swoich nowych obowiązków wywiązywał się wzorowo, o czym być może zostali poinformowani okupanci. Zaraz po kapitulacji spotkał się z nimi bezpośrednio - 4 października w czasie wizyty w budynku gminy gestapo skonfiskowało kasę gminną i zabrało Czerniakowa do swojej siedziby przy al. Szucha. W swoich notatkach podkreślał, że w ramach Einsatzgruppe IV (przekształciła się później w KdS - Kommando der Sicherheitspolizei) kontaktował się z oficerem dosyć wysokiego stopnia, SS-Hauptsturmführerem dr. Bernardem Baatzem, co wskazywałoby, że gestapo od początku było bardzo sprawami żydowskimi zainteresowane. Radę Starszych gminy powołano ostatecznie między 7 a 14 października 1939 r.; od 9 grudnia podlegała nie gestapo, lecz cywilnym niemieckim władzom miasta, którymi kolejno kierowali Helmutt Otto, Oskar Dengel (XI 1939 - III 1940) i Ludwig Leist. W imieniu władz cywilnych od 23 I 1940 r. sprawami żydowskimi zajmował się specjalny Urząd Przesiedleń (Umsiedlungamt) Waldemara Schöna, w praktyce od października 1940 r., czyli od utworzenia getta, do 15 III 1941 r. monopolizujący wszelkie kontakty. Większością spraw zajmował się jeden z wydziałów tego urzędu - tzw. Urząd Transferu (Transferstelle Warschau), kierowany przez Aleksandra Palfingera. W maju zwierzchnia kontrolę nad gettem przejął jako jego komisarz dr Heinz Auerswald z urzędu gubernatora dystryktu. Czerniaków podlegał mu jako Starszy, czy też przewodniczący (Obmann) żydowskiej dzielnicy mieszkaniowej. Po Auerswaldzie kontrolę nad gettem przejęło 22 lipca 1942 r. przybyłe z Lublina komando wysiedleńcze.

Jako przewodniczący Rady Czerniaków miał mnóstwo obowiązków, z których, jak uważa Urynowicz, wywiązywał się wzorowo. Po pierwsze, sprawnie skompletował skład Rady, mimo iż wielu kandydatów próbowało się od tego ryzykownego zaszczytu wymówić. Starał się przekonać do współpracy osobistych znajomych, co miało gwarantować niedostanie się do Rady zwykłych karierowiczów oraz przedstawicieli wpływowych środowisk politycznych i społecznych. Urynowicz sądzi, że „to mu się chyba udało”. Zapewne to prawda w przypadku tzw. I Rady; nowi członkowie - wiele osób zdołało bowiem wyjechać z Warszawy - byli raczej przypadkowymi osobami. Po drugie, Czerniakowowi udało się wspólnie z innymi liderami żydowskiej dzielnicy uniemożliwić planowane przez gestapo na początku listopada 
1939 r. natychmiastowe przesiedlenia Żydów w obrębie miasta, mające być wstępnym krokiem do powstania getta. W sprawie wyznaczenia, a później nieco otoczenia murami (budować je zaczęto od 10 IV 1940) terenów, na których przeważała ludność żydowska, jako zagrożonych epidemią tyfusu, nie miał nic do powiedzenia, chociaż próbował z władzami negocjować warunki finansowe związane z ich budową. Później łudził się przez pewien czas, że getto pozostanie otwarte. Najwięcej jednak wysiłku kosztował Czerniakowa okres przesiedleń z i do getta w listopadzie 1940. Czy liczył wówczas, że de facto istnienie getta wpłynie na normalizację życia Żydów? Zapewne odetchnął z ulgą, gdy w następnych miesiącach terror uliczny i niemiecka samowola znacznie się zmniejszyły. Czasami, jak w przypadku protestu w sprawie zakazu wstępu Żydów do parków miejskich, wykazywał się dużą odwagą cywilną. W większości spraw, głównie co do granic getta, ponosił porażki. Większą skuteczność miały jego interwencje w sprawie aresztowanych przez gestapo Żydów. Niektórych z nich udało mu się wydostać, a największym sukcesem było wykupienie ponad setki osób, którym w kwietniu 1942 groziła śmierć za opuszczenie getta bez przepustki - ostatecznie uwolniono ich za futra. Największym zaś kompromisem była chyba zgoda na powstanie batalionu pracy, czyli akceptacja wyznaczania przez gminę robotników przymusowych w zamian za ograniczenie doraźnych łapanek ulicznych. Wywożono ich później do obozów pracy. Wiadomo było od początku, że w tej sprawie będą równi i równiejsi. Czy jednak mógł coś zrobić poza apelami i memoriałami, by Żydów w obozach nie bito, by pilnowała ich policja żydowska i zwiększono ich racje żywnościowe? Podobnie niewielki wpływ miał na zaopatrzenie getta w żywność. Może gdyby potrafił - tak jak Rumkowski - przekształcić getto w obóz pracy, sytuacja żywnościowa uległaby poprawie? Wymagałoby to innego, bardziej bezwzględnego i autorytarnego przewodniczącego getta. Podobnie bezradny pozostawał Czerniaków wobec protegowanych przez gestapo kolaborantów, na czele z Abramem Gancwajchem, szefem Urzędu do Walki z Lichwą, osławionej „trzynastki” (od siedziby przy ul. Leszno 13). Jakieś działania zakulisowe wobec nich jednak prowadził, czego pośrednio dowodzi dwukrotne aresztowanie go przez gestapo na skutek donosu. Jest nieco zaskakujące, że w drugiej połowie $1941 \mathrm{r}$. Czerniaków zaczął skłaniać się do opinii, że los mieszkańców getta byłby lżejszy, gdyby zarządzało nim gestapo, a nie władze cywilne. Łatwiej udawało mu się z funkcjonariuszami gestapo porozumieć, sądził też, że ich decyzje opierają się na bardziej racjonalnych, uzasadnionych ekonomicznie podstawach. Spośród niemieckich cywilów cenił jednak Karla Laschtowiczkę, kierownika działu finansowego urzędu niemieckiego prezydenta miasta, szczególnie za wsparcie w sprawie prawa gminy do samodzielnego poboru podatków od mieszkańców getta. Uniknięto w ten sposób różnych nieprawidłowości i nadużyć ze strony urzędników polskiego Urzędu Miejskiego. Codziennymi wrogami getta, jego mieszkańców i samego prezesa byli niemieccy lekarze - Kurt Schrempf we władzach miejskich i Georg Richter kierujący służbą sanitarną w dystrykcie: obaj stosowali jedynie metodę zakazów, przymusowych kwarantann i siania histerii co do grożącego tyfusu. Najgorszy był jednak wspominany Waldemar Schön, szef Umsiedlungamtu, i jego bezpośredni współ- 
pracownicy, szczególnie Max Bischof, kierujący po Palfingerze Urzędem Transferu. Mając w ręku monopol na zaopatrzenie getta w żywność, terroryzowali władze gminy coraz to nowymi żądaniami. Bano się szczególnie planów likwidacji małego getta, co pociągnęłoby za sobą nierozwiązywalne problemy mieszkaniowe. Bischof forsował zakładanie w getcie niemieckich szopów produkcyjnych, w których Żydzi byli niewystarczająco opłacani, i zwalczał zdecydowanie szmugiel i czarny rynek żywnością. Na nasilenie terroru nalegał szczególnie komisarz getta Auerswald, zdaniem Urynowicza jeden $z$ inicjatorów zarządzenia o karze śmierci za opuszczenie getta bez przepustki z 15 X 1941 r. Pierwsza egzekucja miała miejsce 17 XI i Czerniaków nie miał żadnych szans, by się temu bezprawiu przeciwstawić.

Urynowicz słusznie zauważa, że problemem Czerniakowa byli nie tylko okupanci, ale i zatrudniany w gminie personel. Byli to w większości ludzie młodzi, niedoświadczeni (przed wojną Żydów w administracji państwowej i municypalnej nie zatrudniano), protegowani przez wpływowe gettowe osobistości, w sumie niewiele umieli, a on sam nie bardzo miał z czego ich pracę opłacić. Z czasem więc tę pracę traktowano raczej jako zabezpieczenie przed represjami, a nie źródło dochodu, poza szarą sferą korupcji. Nieprzekonująco brzmią pochwały autora, że Czerniaków robił co mógł, by z tymi patologiami walczyć. Cóż bowiem ma znaczyć uwaga, „że Czerniaków starał się nie tylko o to, by zapobiegać nadużyciom urzędników i karać ich, ale dążył do zachowania określonego poziomu etycznego”, jeśli w kolejnym zdaniu autor przyznaje, że przewodniczący spowodował ukaranie jedynie trzech osób i poskarżył się Auerswaldowi, że urzędnicy „demoralizują się i są demoralizowani”. Nie miał żelaznej ręki i wystarczającej bezwzględności, by ukrócić w gminie nieustające interwencje osób pokrzywdzonych w różny sposób, np. rodzin mężczyzn wyznaczonych do batalionu pracy czy biedaków błagających o zapomogę. Judenrat warszawski i jego przewodniczący pod tym względem różnili się diametralnie od getta łódzkiego. Jedno, co oba te światy łączyło, to fakt, że w obu siedziba gminy była azylem dla części żydowskich artystów, literatów i naukowców.

Urynowicz sympatyzując ze swoim bohaterem, dosyć powierzchownie i nieprzekonująco relacjonuje spory, do których dochodziło na posiedzeniach Rady Żydowskiej. Przyznaje, że Czerniaków posiedzenia te zwoływał coraz rzadziej, uważa jednak, że powodem był fakt, że przewodniczący „mocno się rozczarował wieloma członkami Rady, którzy nie umieli sprostać wojennej rzeczywistości. Wielu unikało angażowania się w prace gminy, a inni wykorzystywali swą pozycję dla prywatnych interesów, co na ogół polegało na udzielaniu koncesji w zamian za udziały w przedsiębiorstwach”. Co to za przewodniczący, który nie stara się takiego procederu ukrócić? I jaką w istocie wymowę ma uwaga: „Czerniaków czuł się osamotniony i narzekał, że nie ma się kim posłużyć”? Na zasadzie cichej umowy Rada stała się reprezentacyjną fasadą, a gminą rządził przewodniczący z gronem zaufanych współpracowników - ale czy takiego kręgu nie należy po prostu nazwać kliką? Dla Urynowicza byli to jednak ludzie, „co do których [Czerniaków] był pewien, że podołają trudnościom”, a ich „lojalność pozostawała najważniejszą obok kompetencji cechą, której oczekiwał od współpracowników”. Mało to przekonująca, by nie po- 
wiedzieć - naiwna opinia. Na dodatek autor wpada w dosyć prostą pułapkę. Pisząc jedynie dobrze o swoim bohaterze, nie może sobie pozwolić na zbyt krytyczny stosunek do jego najbliższych współpracowników, np. Józefa Jaszuńskiego, Gustawa Wielikowskiego, czy nawet Izraela Firsta i szczególnie bliskiego Czerniakowowi Józefa Szeryńskiego, w getcie uważanych za co najmniej podejrzanych karierowiczów. Konkluduje więc, że posługiwanie się kolaborantami było nieuniknione i że „głosy, jakoby ludzie ci »omotali go siecią, z której nie mógł się wydostać« i przekonali do całkowitej uległości wobec Niemców, wydają się chybione”.

Z tych samych powodów Urynowicz bez zastanowienia staje po stronie Czerniakowa, gdy relacjonuje jego trudne kontakty z szefem ŻsS (Żydowskiej Samopomocy Społecznej) Michałem Weichertem i przewodniczącym Sekcji Pracy Społecznej w warszawskim oddziale ŻSS Emanuelem Ringelblumem. Przecież Czerniaków robił co mógł, np. „dwukrotnie był współorganizatorem akcji »Miesiąc Dziecka«, szukał rozwiązań, które mogłyby ulżyć doli najuboższych; chciał weryfikacji osób jedzących obiady w kuchniach ludowych, by wykluczyć korzystających podwójnie kosztem najbiedniejszych" itp. Tego typu wyliczanie bezspornie pozytywnych zachowań przewodniczącego nie prowadzi do żadnych naukowych wniosków; dość pamiętać, że getto nie bez powodu powszechnie nazywano piekłem na ziemi, by zdać sobie sprawę z ogromu problemów, z którymi miał do czynienia. Trzeba jednak chłodno rozważyć, jakie były alternatywne możliwości i jakie racje stały za podjętymi przez Czerniakowa decyzjami. Zapewne, wsłuchany w głosy wspomnianych zaufanych współpracowników, wielokrotnie się mylił. Nieco więc arogancko brzmi opinia autora, że „mimo to formułowano pod jego adresem liczne, bezpodstawne zarzuty".

Mocną stroną pracy Urynowicza jest wskazanie na negatywne strony wymuszonej przez Niemców współpracy Gminy Żydowskiej z polskim Urzędem Miejskim. Mimo bardziej niż poprawnych stosunków Czerniakowa z polskim burmistrzem Julianem Kulskim urzędnicy podlegający temu drugiemu w sprawach spornych działali wyłącznie na rzecz polskiej części miasta, nie biorąc zupełnie pod uwagę nędzy i innych problemów getta. Pomniejszano kwoty należne gettu z racji rozmaitych, głównie podatkowych rozliczeń, starano się zająć wszystkie sporne graniczne budynki, odmawiano współfinansowania tzw. obcych celów, czyli komunalnych instytucji na terenie getta, nie podzielono się 40 milionami pozostawionymi dla miasta przez rząd polski i 14 milionami, które pozostały na koncie opieki społecznej. Zabrano też bez skrupułów szpital żydowski na Czystem. Sam Czerniaków był bardzo wrażliwy na wszelkie oznaki antysemityzmu wśród Polaków i celnie takie sytuacje w swoich zapiskach komentował.

Co bardzo cenne, w narracji Urynowicza Czerniaków jako osoba prywatna wypada jako człowiek bardzo uczciwy i pracowity, obdarzony dużą wrażliwością, który do ostatnich dni getta potrafił zdobyć się na wisielczy, gorzki humor. Mimo niezbyt dobrego zdrowia i niedających się wyleczyć skutków dwukrotnego pobicia na gestapo, jak pisze Urynowicz, „do końca potrafił zdobywać się na pocieszanie innych". 
22 lipca 1942 przed budynek gminy zajechało kilka samochodów z gestapowcami i ich ochroną. W gabinecie Czerniakowa szef komanda wysiedleńczego Hermann Höfle podyktował tekst zarządzenia, na mocy którego policja żydowska miała następnego dnia dostarczyć na Umschlaplatz sześciotysięczną partię wysiedleńców. Trudno ocenić, czy - jak pisze Urynowicz - przewodniczący łudził się, że ofiarą wysiedleń padnie jedynie tzw. ludność nieprodukcyjna, czy liczył się z całkowitą zagładą getta. Jak podkreśla autor, od 16 lipca codziennie notował informacje i pogłoski o możliwym wysiedleniu. W czasie wspominanej rozmowy podjął z gestapowcami pertraktacje, jak szeroko można rozumieć kategorię zwolnionych z wysiedleń „pracowników Rady Żydowskiej”. Miał nadzieję, że Niemcy nie wysiedlą więcej niż 60 tys. osób. Przez pierwsze dwa dni rzeczywiście wysiedlono 15 tys. osób, a Niemcy przystali na wyłączenie z deportacji uczniów szkół rzemieślniczych oraz małżonków kobiet pracujących. Granicą jego wytrzymałości było żądanie zgody na wywiezienie dzieci z sierocińców. Kilka godzin później popełnił samobójstwo. 24 lipca został pochowany na Cmentarzu Żydowskim. Wdowa Felicja Czerniaków opuściła getto po dziesięciu dniach dzięki pomocy Abrahama Gepnera, dziewięć miesięcy później aresztowało ją tzw. polskie Kripo (Polska Policja Kryminalna), lecz po dwudniowym pobycie w areszcie została wypuszczona na wolność. Agenci Kripo skonfiskowali także dziennik Czerniakowa, który wdowa odzyskała w nieznanych okolicznościach pod koniec lat czterdziestych.

Zapewne ma rację autor apologetycznej biografii Adama Czerniakowa, gdy pisze: „próbując w życiu różnych środków, od akulturacji, poprzez sprzyjanie syjonizmowi, a na ustępstwach wobec hitlerowskich Niemców kończąc, nigdy nie przekroczył granicy przyzwoitości”. Czerniaków ze wszech miar godny jest pamięci potomnych, mimo iż jeszcze długo spory o ocenę jego działalności pozostaną bardzo gorące. Książka Marcina Urynowicza jest cennym wkładem w tę dyskusję. Niestety, moim zdaniem nie jest wolna od uproszczeń, zbyt łatwych usprawiedliwień i pochopnych uogólnień. Jest raczej głosem zaangażowanego adwokata, żądającego całkowitej rehabilitacji oskarżonego w sytuacji, gdy ława przysięgłych większością głosów zwolniła go z odpowiedzialności z powodu braku dowodów winy. 